\title{
Geomorphological method in the elaboration of hazard maps for flash-floods in the municipality of Jucuarán (EI Salvador)
}

\author{
C. Fernández-Lavado ${ }^{1,2}$, G. Furdada ${ }^{1}$, and M. A. Marqués ${ }^{1}$ \\ ${ }^{1}$ Departament Geodinàmica i Geofísica, Facultat de Geologia, Universitat de Barcelona, Martí i Franquès s/n, 08028 \\ Barcelona, Spain \\ ${ }^{2}$ World Geologists, Av. Parallel 144-146, 08015 Barcelona, Spain
}

Received: 8 March 2007 - Revised: 22 June 2007 - Accepted: 27 June 2007 - Published: 18 July 2007

\begin{abstract}
This work deals with the elaboration of flood hazard maps. These maps reflect the areas prone to floods based on the effects of Hurricane Mitch in the Municipality of Jucuarán of El Salvador. Stream channels located in the coastal range in the SE of El Salvador flow into the Pacific Ocean and generate alluvial fans. Communities often inhabit these fans can be affected by floods. The geomorphology of these stream basins is associated with small areas, steep slopes, well developed regolite and extensive deforestation. These features play a key role in the generation of flash-floods. This zone lacks comprehensive rainfall data and gauging stations. The most detailed topographic maps are on a scale of 1:25 000. Given that the scale was not sufficiently detailed, we used aerial photographs enlarged to the scale of 1:8000. The effects of Hurricane Mitch mapped on these photographs were regarded as the reference event. Flood maps have a dual purpose (1) community emergency plans, (2) regional land use planning carried out by local authorities. The geomorphological method is based on mapping the geomorphological evidence (alluvial fans, preferential stream channels, erosion and sedimentation, man-made terraces). Following the interpretation of the photographs this information was validated on the field and complemented by eyewitness reports such as the height of water and flow typology. In addition, community workshops were organized to obtain information about the evolution and the impact of the phenomena. The superimposition of this information enables us to obtain a comprehensive geomorphological map. Another aim of the study was the calculation of the peak discharge using the Manning and the paleohydraulic methods and estimates based on geomorphologic criterion. The results were compared with those obtained using the rational method. Significant differences in the order of magnitude of the calculated discharges were noted. The rational method underestimated
\end{abstract}

Correspondence to: C. Fernández-Lavado

(cfedez@gmail.com) the results owing to short and discontinuous periods of rainfall data with the result that probabilistic equations cannot be applied. The Manning method yields a wide range of results because of its dependence on the roughness coefficient. The paleohydraulic method yielded higher values than the rational and Manning methods. However, it should be pointed out that it is possible that bigger boulders could have been moved had they existed. These discharge values are lower than those obtained by the geomorphological estimates, i.e. much closer to reality. The flood hazard maps were derived from the comprehensive geomorphological map. Three categories of hazard were established (very high, high and moderate) using flood energy, water height and velocity flow deduced from geomorphological and eyewitness reports.

\section{Introduction}

Flooding is regarded as one of the most dangerous natural hazards and as a principal trigger of disasters (AlcántaraAyala, 2002). One of the methods to curb the catastrophic effects of floods is to use hazard maps applied to regional/local planning management with the cooperation of national and local authorities (Montz and Gruntfest, 2002).

Nowadays the general tendency is to produce hazard flood maps using rainfall data and computer-based models. The data needed in these models include a comprehensive register of daily rainfall data, roughness coefficients of the channel and detailed topographic maps or DEMs. Nevertheless, when the quality of data is poor the results of the models are not real. In developing countries like El Salvador, there is a lack of data, with the result that these methods cannot be applied because the results are unreliable.

On 21 October 1998 the National Hurricane Center of the USA identified a low pressure area over the Caribbean Sea. On 22 October this depression evolved into a tropical storm known as Mitch. Between 23 and 26 October winds rose up

Published by Copernicus Publications on behalf of the European Geosciences Union. 
to $300 \mathrm{~km} / \mathrm{h}$ (category 5 in Saffir-Simpson Hurricane scale). In some places of El Salvador the rainfall recorded was about $400 \mathrm{~mm} /$ day, which accounts for almost $30 \%$ of the average annual rainfall of the whole country. Along the Pacific coast many communities that inhabited the alluvial fans located in the lower reaches of the stream channels were affected. These alluvial fans are activated when a flash-flood occurs resulting in erosion and sedimentation. Because of the floods and landslides, 374 people lost their lives and about 56000 were displaced. Material losses were estimated at 398 million U.S.\$. Hurricane Mitch triggered the most catastrophic floods in Central America in modern times (Neumann, 2000)

Studying the effects of Hurricane Mitch will enable us to reconstruct the extreme reference event in the zone. The Mitch hurricane was an extreme event, and in such events precipitation is not homogeneous in time and along their route. For instance, in Nicaragua accumulated rainfalls related to the Mitch hurricane can vary from less than 100 years ( 75 years for Leon) to 500 years return period (Condega and San Isidro), calculated with the longest rainfall series existing in the country (1966 to 1998) (INETER, 1998). Also in El Salvador, accumulated rainfalls nearby our study zone (pluviometer located in San Miguel, $20 \mathrm{~km}$ North of the mountainous study area) vary from 25 to 80 years return period using a 20 year rainfall series depending on the statistical method used, i.e. Type-I Gumbel distribution, GEV, SQRT (Ferrés et al., 2002). On the other hand, the effects in Quebrada Seca correspond to an extreme event, as it is shown in the following sections.

\subsection{Study area}

Central America is a prone region to hurricanes coming from the Caribbean Sea between July and December. These hurricanes can provoke long and intense rainfall causing severe flooding. The region is also affected by tropical storms between May and November.

El Salvador occupies an area of $21000 \mathrm{~km}^{2}$. Geologically El Salvador is a very active country. The Cocos plate subducts under the Caribbean plate and forms the volcanic range that extends along the country in a NW-SE direction.

The study area (Fig. 1) is located in the municipality of Jucuarán (SE El Salvador). The municipality has an area of $32.7 \mathrm{~km}^{2}$ and is characterized by stream channels running from the coastal range to the Pacific Ocean. In the study area there are effusive rocks forming part of the Bálsamo unit defined as a succession of basic and intermediate effusive volcanic rocks, pyroclastites and epiclastites (Baxter, 1984) which readily disintegrate.

The flood hazard analysis was focused on the lower reaches of five stream channels flowing into the Pacific Ocean. Most of the communities currently inhabit this zone which was affected by Hurricane Mitch.

\subsection{Geomorphological context}

The study area consists largely of alluvial fans in the lower reaches of the stream channels. The gradient of these channels varies between $8 \%$ and $16 \%$ and the basins of these channels occupy areas from $1.6 \mathrm{~km}^{2}$ to $18 \mathrm{~km}^{2}$. Soils are usually regolites that disintegrate without difficulty. Land use is characterized by ever increasing crop cultivation and deforestation (Fernández-Lavado, 2006).

These characteristics provide conditions for flash-floods (Camarasa and Segura Beltrán, 2001) which include a large amount of solid material deposited by landslides coming down the adjacent slopes (Larsen and Simon, 1993; Guinau et al., 2005). This dynamics generate the reactivation of alluvial fans when rainfall intensity and magnitude are exceptional as in the case of hurricane Mitch.

One important feature of a flash-flood is the short time between the meteorological phenomenon and generation of the flood (Handmer and Gruntfest, 2001). During Hurricane Mitch, large basin rivers such as the Lempa and the San Miguel Rivers had high water levels for several days. On the other hand, channels in our zone displayed a torrential behaviour and water levels went down once the rainfall intensity diminished. This sort of flood lasts few hours but with devastating consequences.

\subsection{Available data}

El Salvador is a developing country and has few resources. In the study area there are no gauging stations. There are no pluviographs. Pluviometers that are already located are insufficient and rainfall records are available for few years and are discontinuous. Topographic maps are slightly detailed (1:25000 scale). In a real flood, water levels can range from centimeters to a few meters. The distance between contour lines in the available maps is $20 \mathrm{~m}$ with the result that these maps are of little use for constructing flood hazard maps. DEMs do not exist. A rough approach, useful for general description of the region, can be constructed from the contour lines of the 1:25000 topographic map, equidistant $20 \mathrm{~m}$, and the few extra points indicating altitudes on the map (TIN extension of ArcGIS). In consequence, the resolution of the DEM is not enough to reconstruct the topography of the channel affected by the floods at an appropriate scale. Because of this, cross sections can not be extracted systematically from the DEM in order to calculate discharges.

Vertical aerial photographs from December 1998 were acquired (Open Skies post Hurricane Mitch aerial photography, USGS). They are not orthophotographs but they gave us a high resolution of the zone. The photographs were enlarged in order to work at approx. 1:8000 scale. Despite the distortions of the aerial photographs, these detailed and enlarged photographs provide more and better information than the 1:25000 scale topographic maps. The main geomorphologic effects of Hurricane Mitch are still visible. Using these 


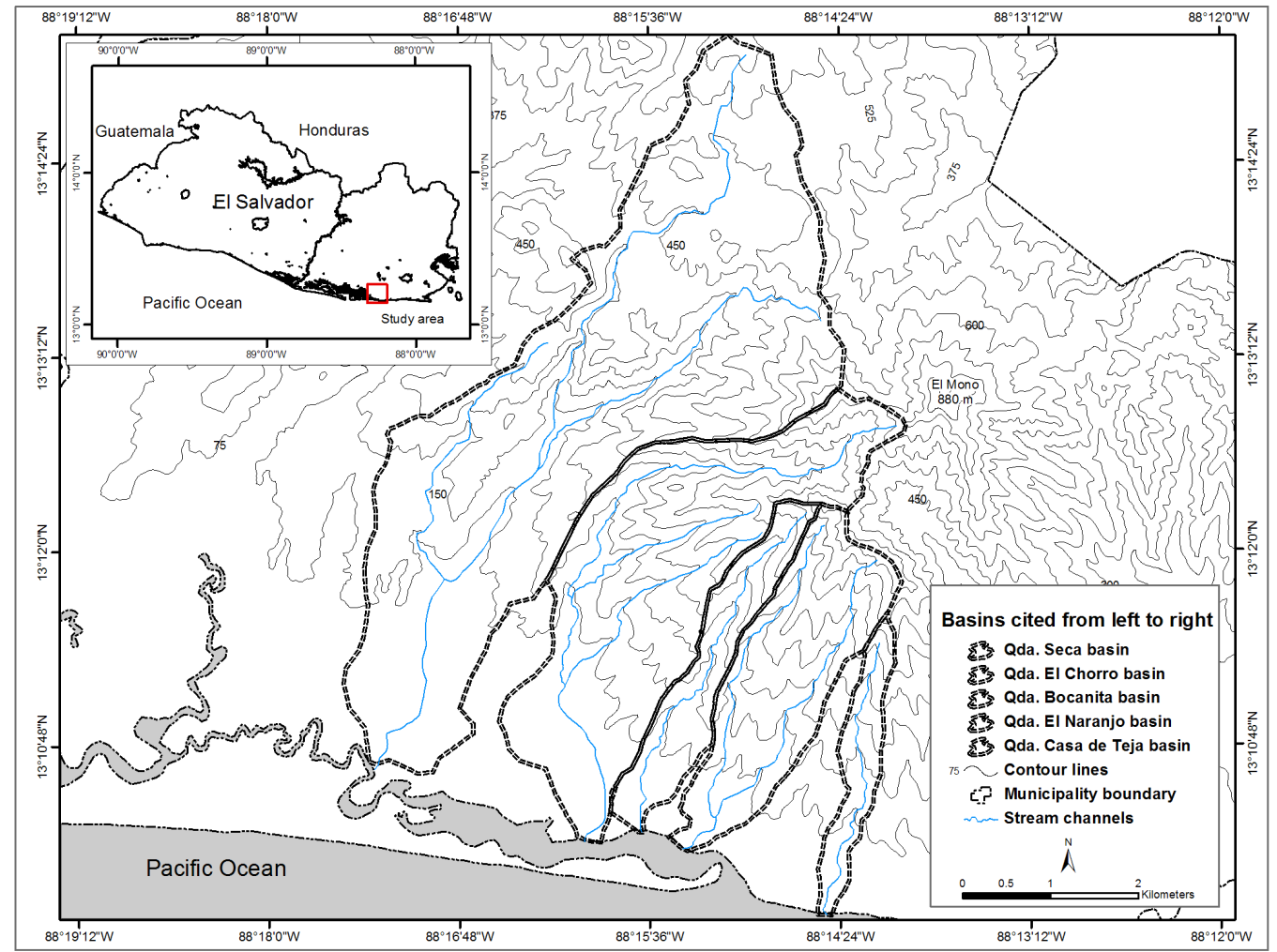

Fig. 1. Study Area. El Salvador is the smallest country in the Central American isthmus.

photographs it is possible to locate the evidence of flooding and to construct a geomorphologic map that reflects all the features and characteristics modelled by the reference flood. The resulting geomorphological features will exert an influence on future floods.

\section{Methodology}

Most hydrological studies are focused on obtaining peak discharges to determine floods. Other studies concern geomorphological and historical information (Arnaud-Fassetta et al., 2004; Ballais et al., 2005). In this study we adopted the two approaches. On one hand, the geomorphological analysis of evidence and eyewitness reports (Témez, 1997) constitute the basis for the comprehensive geomorphological map. On the other hand, the calculation of discharge values during the peak discharge provides us with an order of magnitude of the flow. Both these approaches will enable us to give an overall view of the phenomenon and to discuss the validity of the methods used.

\subsection{Integrated geomorphological method}

The geomorphological evidence is obtained using three complementary techniques, as described below. The integrated geomorphological map is constructed with this evidence (Furdada et al., 2007). The method is very similar to that used by Arnaud-Fassetta et al. (2004) and Ballais et al. (2005) but adapted to the characteristics and constraints of Central America (Furdada et al., 2007).

\subsubsection{Vertical aerial photointerpretation}

Photointerpretation precedes the fieldwork. The preliminary analysis provides a geomorphological scenario that conditions the processes during the flood. In the case of alluvial fans channel migration and decreasing sediment distribution along the fan and other processes can be expected. The analysis is focused on the lower reaches of the channels and alluvial fans given that the higher reaches are abrupt and uninhabited.

The aerial photographs of December 1998 show a number of geomorphological effects caused by hurricane Mitch (Fig. 2a). These effects include reactivation of alluvial fans, preferential stream channels, stagnant water, overflow in meanders, erosion and deposition zones. In addition a number of anthropic constructions influencing the flood i.e. manmade terraces to cultivate cotton can also be identified. 


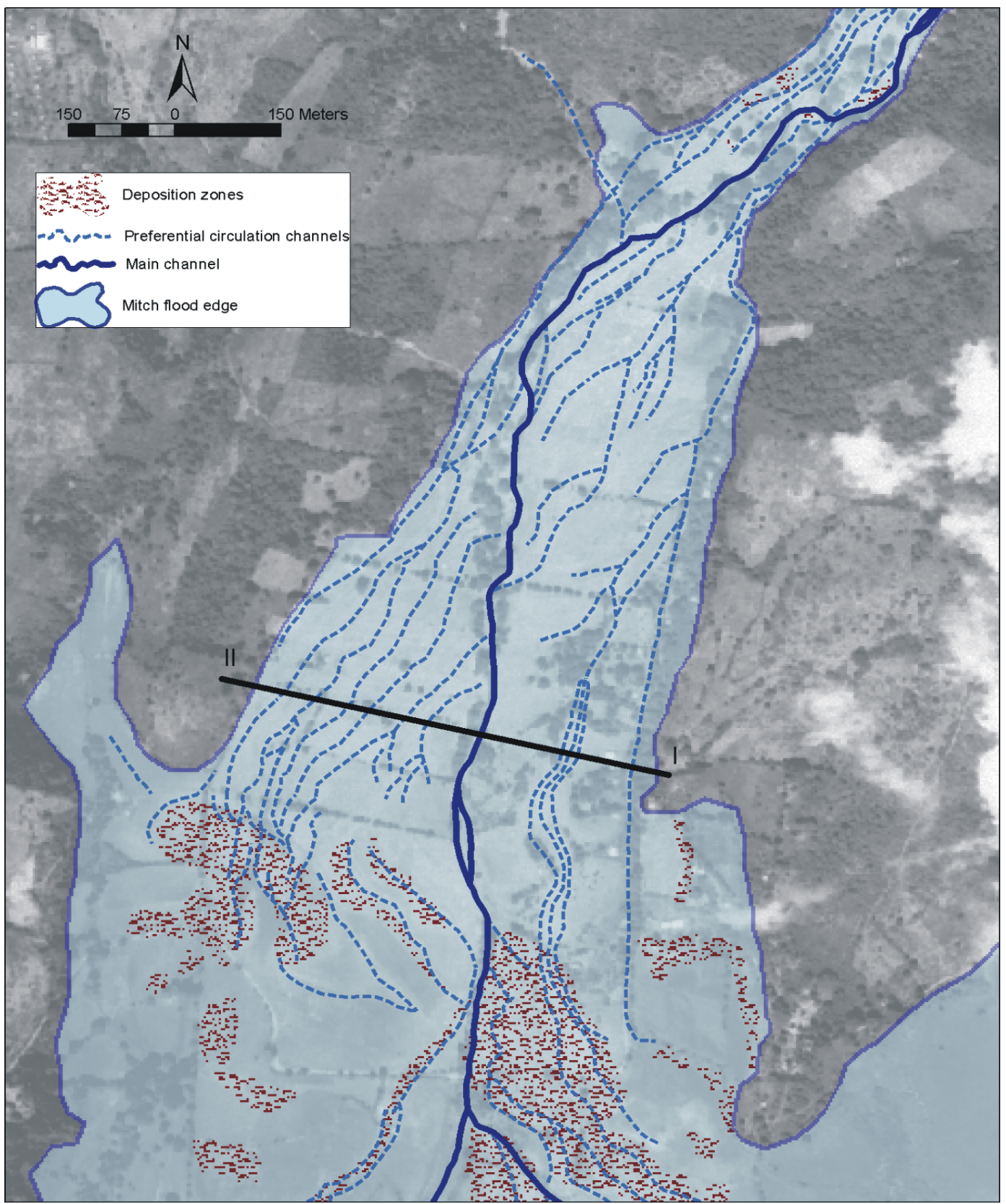

Fig. 2. Photointerpretation. Observations: main channel, preferential circulation channels and sedimentation zones. Location of the cross section used for the general geomorphological estimation of the flow is shown (see Sect. 2.2.3.).

\subsubsection{Fieldwork and eyewitness reports}

Evidence from aerial photographs is corroborated during fieldwork and eyewitness reports are obtained from local people: (1) field evidence: critical points of overflow, big boulders displaced by flow energy, tree roots covered by fine sediments, vegetation influence and sediment retention, etc. and (2) eyewitness reports: high water levels during peak discharge, material transported by flood, damage caused by flow, etc. which give an idea of the energy of the flash flood (Figs. 3a-c).

\subsubsection{Community workshop}

The aim of the community workshop is to obtain a historical perspective and specific information about the reference event (Hurricane Mitch in this case) complemented with eyewitnesses reports obtained during field work. People are divided into groups to discuss the enlarged aerial photographs (Fig. 3d). It should be noted that people are able to recognise their houses and identify community infrastructures and all the effects related to the reference flood without difficulty. The limits of the flooded area were drawn as well as water 
height, damage, buildings and structural elements within the community. In order to establish the return periods of different flash floods, people were asked about past floods, but in this case no one in the community could recall a flood that matched Hurricane Mitch in magnitude. Nevertheless, the oldest people in the community were able to recall Hurricane Fifí in 1974. This information gives us an idea of the frequency of large magnitude floods. The consequences of Hurricane Fifí were not as devastating as those of hurricane Mitch. Other aims of the workshop included the preservation of the historical memory of the community as well as raising the awareness of future floods.

\subsection{Discharge calculations}

This section is concerned with estimating peak discharge values during the flood. In addition, these discharge values are usually used as input data in flood computer models. Here, we summarize the calculations employing the different methods normally used by technicians and practitioners. Our aim is to highlight the limitations of computer-based models that are sometimes used without a criterion.

The quality of the data must be evaluated for all the methods in order obtain reliable results (Maizels, 1983). This is of especial importance in areas with little data. The rational method, for instance, depends on rainfall data series lasting for few years and that are discontinuous in our zone. Nevertheless, prior studies in Quebrada Seca stream were undertaken to obtain a peak discharge, using rainfall records not exceeding 15 years. The pluviometer is located in El Transito Municipality, $10 \mathrm{~km}$ North-West of the study area; Type-I Gumbel distribution was applied to obtain return period rainfall values. Intensity rainfall derived from daily precipitation, and run-off values were calculated and the rational method applied) (Torrecilla et al., 2003). Results ranged between $150 \mathrm{~m}^{3} / \mathrm{s}$ and $200 \mathrm{~m}^{3} / \mathrm{s}$.

In our study the Manning (Benson and Dalrymple, 1967) and the paleohydraulic (Costa, 1983) methods were also used. Our peak discharge results were compared with those obtained by Torrecilla et al. (2003), cited above. The calculations were made in the Quebrada Seca stream since this has the largest fan in all the studied area. It is the stream that causes most damage during floods.

To apply the Manning and the Paleohydraulic methods, one cross section was obtained. This section was measured in the field by using a compass, a clinometers and a meter tape measure, and with the aid of a native inhabitant who cleared off the vegetation grown since 1998. The slope of the channel was obtained also in the field, close to the cross section and along the lowest terrace. The location of the cross section was carefully chosen. As commented in section 1.3., topographic maps at 1:25000 scale were useless to build cross sections at an appropriate scale and the difficulty of access (rainforest) made very difficult to obtain series of cross sections. It was assumed that all the water that spread over the

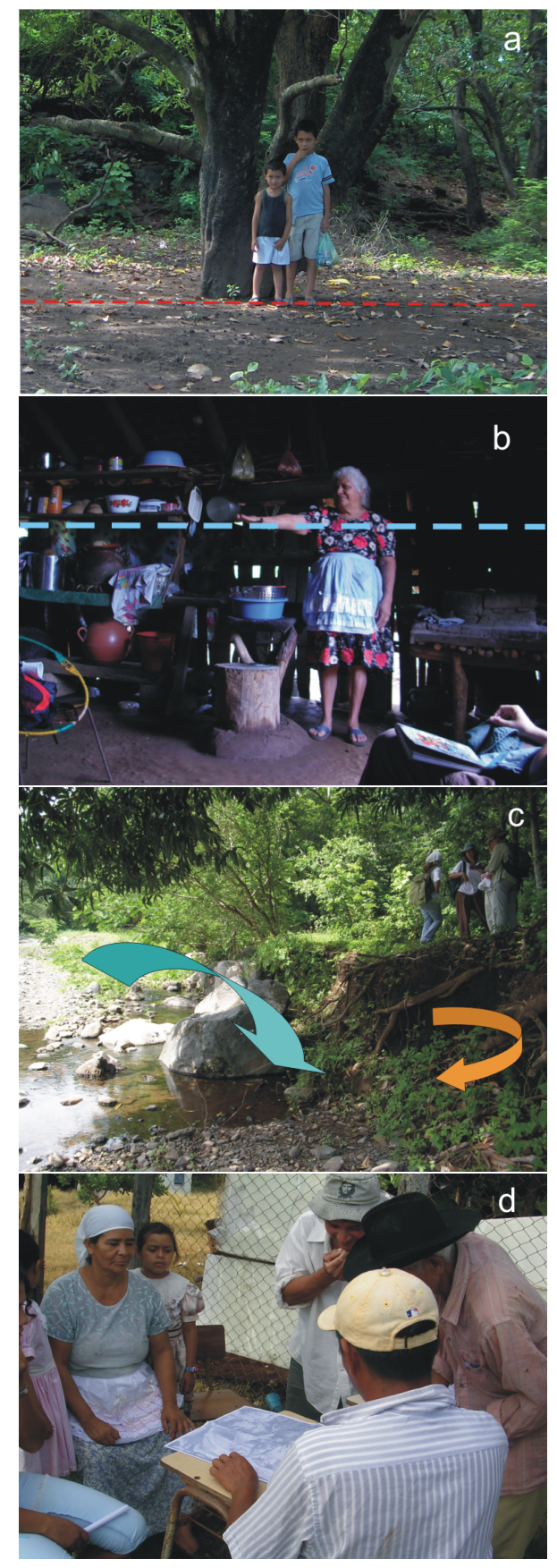

Fig. 3. Integrated geomorphological method. Techniques and indicators employed. (a) Tree roots covered by fine sediments, indicating low flood energy. The red line indicates the surface of the fine sediment deposited, covering the base of the trunk, at the level of the tree. (b) Woman indicating water level inside her house during flash-flood peak. (c) Displacement of large boulders. Undermining in a meander. Critical overflow points were, in some cases, water canalizes to preferential circulation channels. (d) Community Workshop. Persons working with enlarged aerial photographs. 


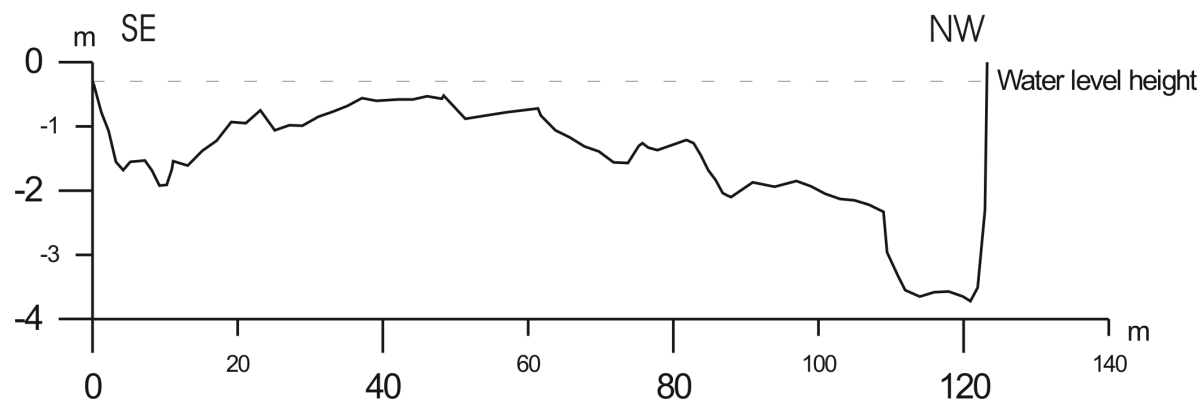

Fig. 4. Cross section made in Quebrada Seca at the apex of the alluvial fan. The Manning and the paleohydraulic methods were applied. The section was obtained in the field, using compass, clinometers and a meter tape measure.

Table 1. Discharges obtained with different methods. $\mathrm{Q}_{r}-$ Discharge calculation obtained from the rational method. $\mathrm{Q}_{m}-$ Discharge calculation obtained from the Manning method; $\mathrm{Q}_{p}-$ Discharge calculation obtained from the paleohydraulic method; $\mathrm{Q}_{g}-$ Discharge estimate obtained from geomorphologic evidence.

\begin{tabular}{ccccc}
\hline \multicolumn{5}{c}{ Discharge $\left(\mathrm{m}^{3} / \mathrm{s}\right)$} \\
\hline & $\mathrm{Q}_{r}$ (Torrecilla et al., 2003) & $\mathrm{Q}_{m}$ & $\mathrm{Q}_{p}$ & $\mathrm{Q}_{g}$ \\
\hline Qda. Seca & $138-184$ & $288-672$ & 779 & $\sim 3000$ \\
\hline
\end{tabular}

alluvial fan had passed through this section (Fig. 4), located near the apex of the alluvial fan.

In addition, an estimate using geomorphological criterion was made, which enabled us to analyze more critically the methods employed (Table 1).

\subsubsection{The Manning method}

In order to apply the Manning equation, the area corresponding to the cross section of the stream (Fig. 4) is needed to calculate peak discharge (Harrelson et al., 1994). Subsequently the Manning equation was used:

$Q=\frac{A \times R^{\frac{2}{3}} \times j^{\frac{1}{2}}}{\eta}$

where $Q$ is the discharge, $R$ is the hydraulic radius $\left(A / \mathrm{W}_{p}\right)$, A is the area of the cross section, $\mathrm{W}_{p}$ is the wet perimeter, $j$ is the channel slope and $\eta$ is the roughness coefficient.

The selected roughness coefficient values ranged between 0.03 associated with mountain channels with gravel and a few boulders and 0.07 associated with mountain channels with large boulders (Chow, 1959). Benson and Dalrimple (1967) propose values related to the channel characteristics from 0.028 to 0.035 (gravels) and until 0.07 (boulders). We assume that the values 0.03 and 0.07 represent well enough the possible range of coefficients applicable to Quebrada Seca, even though values ranging from 0.04 to 0.07 could be more appropriate.
Discharges obtained from this data ranged from $288 \mathrm{~m}^{3} / \mathrm{s}$ to $672 \mathrm{~m}^{3} / \mathrm{s}$ (Table 1). Using this equation, the results are very sensitive to the roughness coefficients selected.

\subsubsection{The Paleohydraulic method}

The paleohydraulic method developed by Costa (1983) and applied to a number of studies (Alcoverro et al., 1999; Williams, 1984) is based on obtaining the mean velocity of flow by means of the intermediate axis of the largest boulders moved by the flow. The following equation was used (Costa, 1983):

$v=0.182 \times d^{0.4873}$

where $v$ is the velocity, $d$ is the mean value of five intermediate axes of the five largest boulders displaced by flood. Downwards the section (Fig. 4), a number of blocs that had been transported across it by the flow (eyewitness and $\mathrm{Al}-$ coverro et al., 1999) was measured and the five largest blocs were selected. The resulting $d$ value was $1462 \mathrm{~mm}$, which means a velocity of $6.21 \mathrm{~m} / \mathrm{s}$. Once the velocity and the area of the cross section are known (Fig. 4), the following equation can be applied:

$Q=A \times v$

where $\mathrm{Q}$ is the discharge, $\mathrm{A}$ is the area of the cross section and $v$ is the velocity. The discharge obtained is around $780 \mathrm{~m}^{3} / \mathrm{s}$ (Table 1 ).

\subsubsection{Estimate derived from geomorphological criteria}

The discharge in the middle part of alluvial fan was estimated (Fig. 2a). This estimate was used to obtain an approximate discharge value that represented only one order of magnitude of the flow. The cross section was obtained using GIS techniques. A rough DEM, useful for other purposes than obtaining cross sections, was constructed from the topographic map at a scale of 1:25000 (see Sect. 1.3). The DEM allowed us to draw a rough, approximate cross section in the alluvial fan (Fig. 2). The limits of the flood and the height of the water level were well known: the flood occupied the whole width 


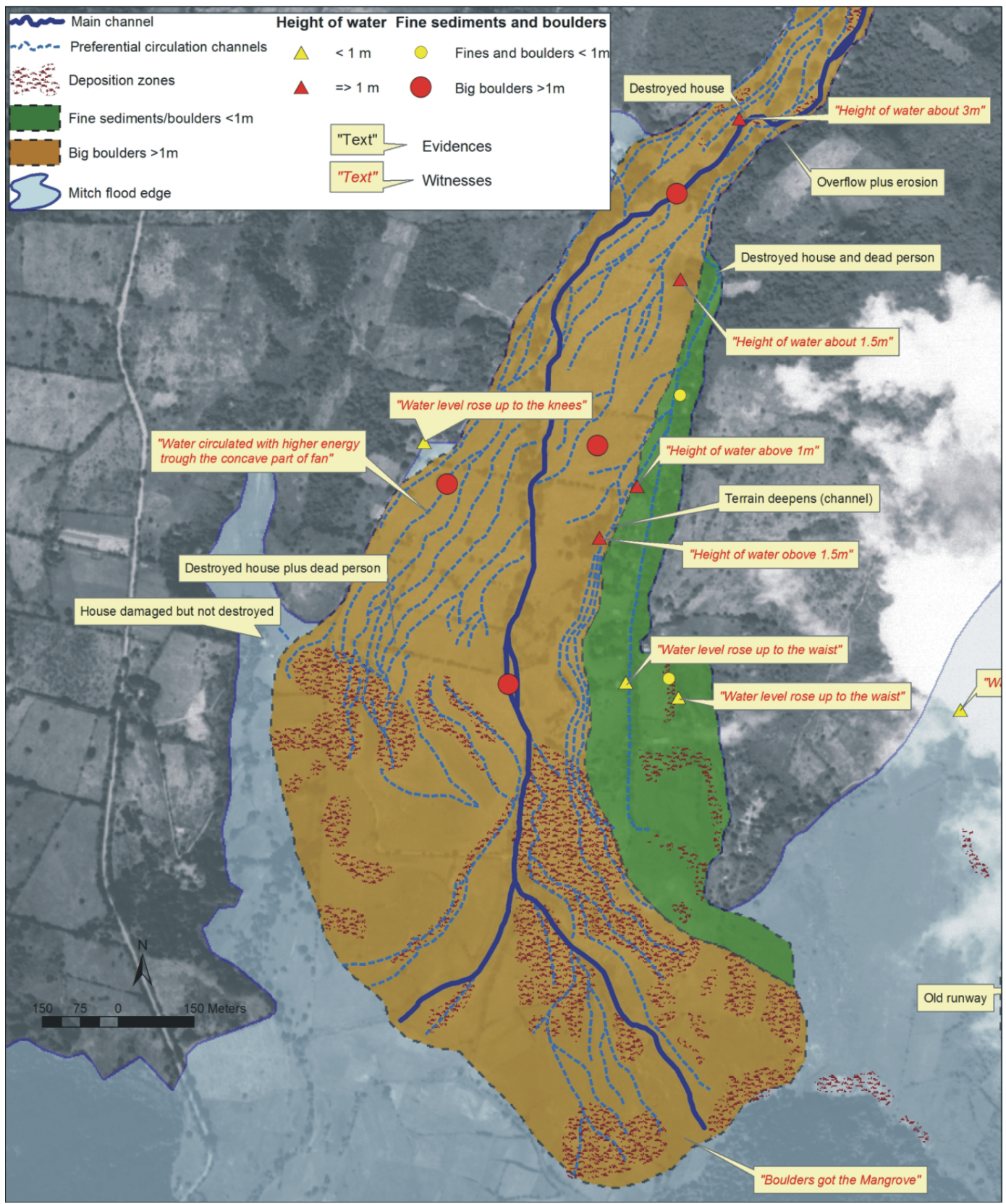

Fig. 5. Geomorphological indicators map at Quebrada Seca stream.

of the alluvial fan; the water level was at least about 1 meter (witnesses information). Then the area of the cross section occupied by the flood was calculated. This was rough, but real information. Velocity flow was not calculated, but estimated at $4 \mathrm{~m} / \mathrm{s}$ using damage and displaced boulders. It was considered lower than the velocity calculated at the upstream cross section because of the following reasons: 1) water spreads over the alluvial fan, and consequently the water level falls (Fig. 3b) and velocity decreases; 2) during the peak discharge, water spreads over the fan, and velocity is higher in the preferential circulation channels than in the intermedi- ate zones; 3 ) the flow velocity in the preferential circulation channels during the peak discharge has to be high enough to transport large boulders. The area of the cross section was about $780 \mathrm{~m}^{2}$. With the aid of these data Eq. (3) can be used to obtain a discharge value of about $3000 \mathrm{~m}^{3} / \mathrm{s}$ (Table 1).

\subsubsection{Limitations of the methods}

It should be pointed out that the rational method underestimated the results with respect to those of the other methods used in this work. This may be due to the availability rainfall 
Table 2. Hazard ranges in Jucuarán Municipality derived from Hurricane Mitch effects. Classification made using water energy and water level criteria. Velocity estimated by the paleohydraulic method.

\begin{tabular}{|c|c|c|c|c|}
\hline Hazard & Water energy & & Height (h) & Height $(h) \times$ velocity $(v)$ \\
\hline Very high & Boulders & +4 & $\mathrm{~h} \geq 1 \mathrm{~m}$ & $\mathrm{~h} \times \mathrm{v} \geq 5 \mathrm{~m}^{2} / \mathrm{s}$ \\
\hline High & & & $1>\mathrm{h}>0.5 \mathrm{~m}$ & $5 \mathrm{~m}^{2} / \mathrm{s}>\mathrm{h} \times \mathrm{V}>0.5 \mathrm{~m}^{2} / \mathrm{s}$ \\
\hline Moderate & Sand and pebbles & $-\downarrow$ & $\mathrm{h} \leq 0.5 \mathrm{~m}$ & $\mathrm{v} \times \mathrm{h} \leq 0.5 \mathrm{~m}^{2} / \mathrm{s}$ \\
\hline
\end{tabular}

records that are discontinuous and cover few years. These data do not therefore reflect the real evolution of rainfall during a long period of time in our zone. Other limitations include the application of probabilistic methods, run-off coefficient election, etc. (Ayala-Carcedo, 2001).

As regards the other methods, a number of considerations must be borne in mind when analysing the results.

The Manning method depends on a number of variables. Of these, slope, water height and especially the roughness coefficient can considerably vary the results (Benson and Dalrymple, 1967). Channel erosion, which is directly influenced by channel slope, is very often overlooked. The water often leaves marks along the river channels, often used to reconstruct the water level a posteriori. The water level varies during a flood and usually, the marks along the channel are assumed to correspond to the peak discharge water level. As the erosion incises the stream, the stream bed deepens with the result that the water level descends. In this case, the water mark would be erroneous and the resulting discharge overestimated. This can be the scenario for steep stream channels (Jarrett, 1986). The opposite scenario can also happen. During peak discharge the area of the cross section of the channel can be larger than the area measured after the flood. This may be due to the filling of the channel with sediments when flow energy diminishes after peak discharge. This could have happened in the lower reaches of the channel and the alluvial fan in Quebrada Seca. In this case, the discharge could have been underestimated.

When using the paleohydraulic method it is necessary to be sure that boulders were transported by the flood and they passed through the section where the velocity is calculated (Alcoverro et al., 1999). Another difficultiy of the application of this method is that velocity can be very variable across the section. In addition, during one of these extreme events, several flood peaks can happen. Also, in alluvial fans the properties of the flow can vary and change from a water flow transporting bed load and fines to a debris flow (that can easily transport big boulders). Even though, in this case and supported on witness information, it seems that there was at least one very important discharge peak (not a debris flow) and the flow (water plus sediment) covered all the alluvial fan. During this flow peak some large boulders were trans- ported and deposited near the houses, downwards the considered cross section (houses flooded, inhabitants went out, and when they came back the big boulders were found besides the houses; no evidence of debris flow deposits were found in these cases) (Fig. 5). We deduce, then, that the boulders measured (or other boulders of the same size) could be transported across the section by the flow, at least during the most important peak. Another of the limitations of this method is that we cannot be sure whether the flow could have transported larger boulders. The size of the transported blocks depends on the maximum size of the available blocks, on the size distribution of all particles in the load and on the energy of the flow (Selby, 1991). The size of the blocks is controlled firstly by the lithology and the discontinuities of the bedrock, and finally by the alteration of this fragmented bedrock which becomes the regolite; this regolite, including the blocks, is eroded and incorporated to the stream. If the flow had transported larger boulders (i.e. not available in the basin) the resulting discharges would be underestimated.

In our work Manning and paleohydraulic methods were applied in one of the best possible cross sections (approx. $300 \mathrm{~m}$ North of the map in Figs. 2, 5 and 6), made at the apex of the alluvial fan and assuming that the flow that spread over the fan must have passed trough this section.

The estimate based on geomorphological criteria is about one order of magnitude higher than those calculated with the paleohydraulic and the Manning methods. This estimate is based on real data or on data directly derived from the real data (extension of the fan affected by the flow and water level height, obtained form geomorphological evidence and witness). This result may be considered to be closer to reality than the other results. Channels can be modified during flood last stages, and sediment redistributed and deposited, but this is not considered in our rough estimation. The aim of our rough estimation is just to point out that, taking into account the geomorphological frame or scenario (i.e. the alluvial fan and its limits in this particular case), calculated flows can be "calibrated" (or at least compared to an extreme value, used as a reference) and assumptions and hypothesis used to calculate flows can be reconsidered if necessary. The limitations of the different methods discussed above exert a considerable influence on the discharge calculation in large flash-floods. The use of geomorphological indicators together with real data enables us to assess the validity of the results obtained by other methods.

\section{Results}

From the comprehensive/integrated geomorphological map (Fig. 5) we can construct a hazard map (Fig. 6).

Flood hazard evaluation methods are mostly based on flood frequency, height and velocity of the flow or, like in Neumann (2000), a combination of all these parameters (including height per velocity). Several authors propose to se- 


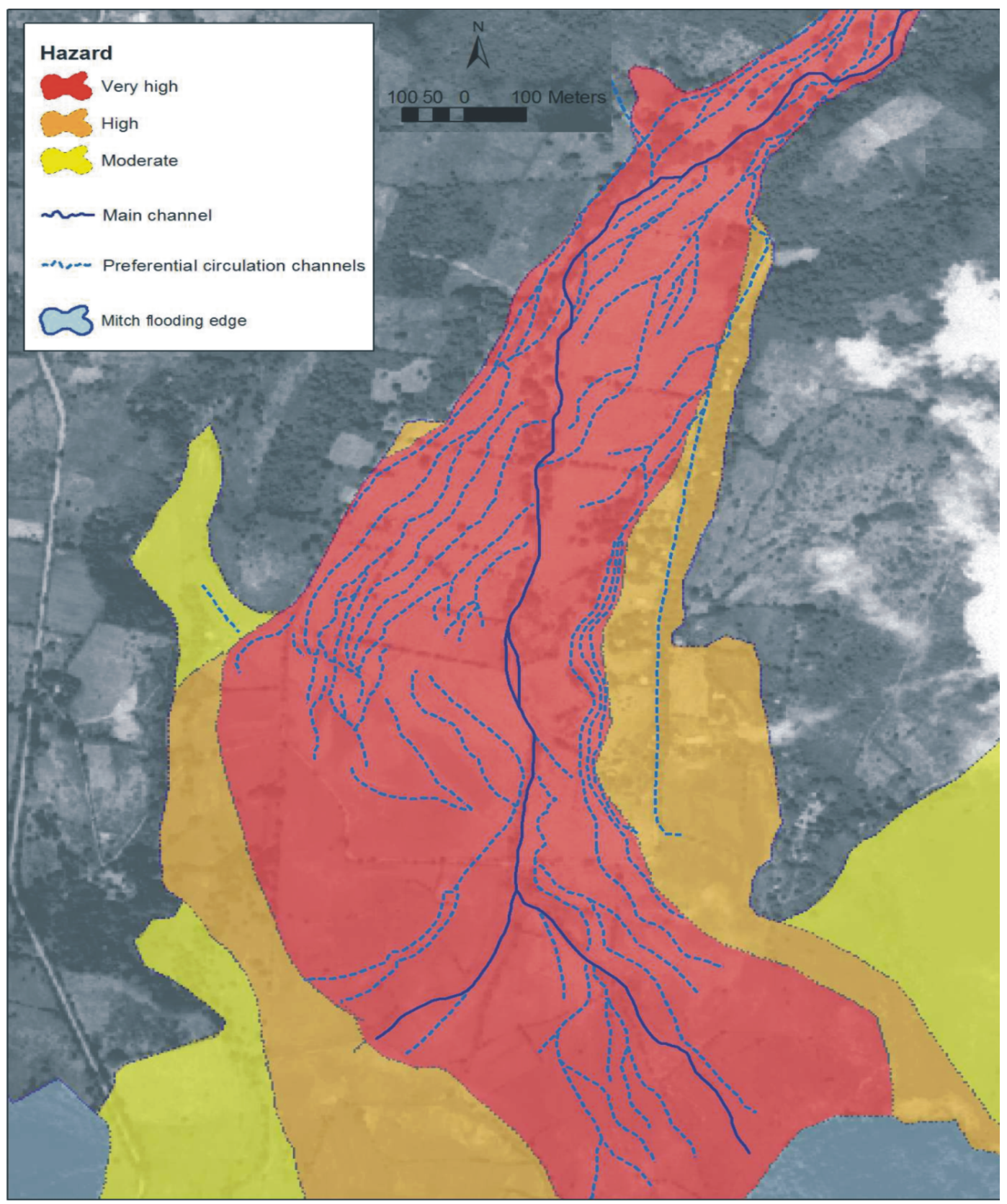

Fig. 6. Flood Hazard map at Quebrada Seca stream.

lect a reference event and to elaborate the hazard zoning based on the flow height and velocity for this event. For instance, ACA (Generalitat de Catalunya) (2003) propose to take the 100 years return period event; for this event the high hazard level corresponds to a flood height $>1 \mathrm{~m}$, flow velocity $>1 \mathrm{~m} / \mathrm{s}$, or the product of height per velocity $>0.5 \mathrm{~m}^{2} / \mathrm{s}$; the moderate hazard level corresponds to a flood height $>0.4 \mathrm{~m}$, flow velocity $>0.4 \mathrm{~m} / \mathrm{s}$, or the product of height per velocity $>0.08 \mathrm{~m}^{2} / \mathrm{s}$. The Ministère de l'Aménagement du Territoire et de l'Environnement Française (MATE), in the Plans de prévention des risques naturels previsibles : risque d'inondation (1999) proposes a similar approach, and specifically treat flash floods: for a 100 years return period flood, the low hazard corresponds to a flood height $<0.5 \mathrm{~m}$ or/and a flow velocity $<0.2 \mathrm{~m} / \mathrm{s}$; the medium hazard corresponds to a to a flood height (h) $0.5 \mathrm{~m}<\mathrm{h}<1 \mathrm{~m}$ or/and a flow velocity (v) $0.2 \mathrm{~m} / \mathrm{s}<\mathrm{v}<0.5 \mathrm{~m} / \mathrm{s}$; the high hazard corresponds to a to a flood height $>1 \mathrm{~m}$ or a flow velocity $>0.5 \mathrm{~m} / \mathrm{s}$; and the very high hazard corresponds to a flood height $>1 \mathrm{~m}$ and a flow velocity $>0.5 \mathrm{~m} / \mathrm{s}$.

We lacked sufficient data to make a hazard map based on the return periods. But the Mitch associated flood was, with 
no doubt, a very low frequency, extreme event. So we take this event as the reference one. We obtained sufficient information about water levels and flow energy from geomorphological analyses and eyewitness reports to construct a map. We can superimpose all these data (synthesized in Fig. 5) to elaborate a hazard classification (Table 2):

Very high hazard zone. Big boulders displaced by flow energy. Water levels above $1 \mathrm{~m}$ and/or the result of multiplying velocity (v) and height (h) exceeds $5 \mathrm{~m}^{2} / \mathrm{s}$ (where velocity is estimated by the paleohydraulic method).

High hazard zone. Medium boulders and cobbles displaced by flow energy. Water levels between $0.5 \mathrm{~m}$ and $1 \mathrm{~m}$. The result of multiplying velocity (v) and height (h) ranges between $0.5 \mathrm{~m}^{2} / \mathrm{s}$ and $5 \mathrm{~m}^{2} / \mathrm{s}$ (where velocity is estimated by the paleohydraulic method).

Moderate hazard zone. Gravels and sands displaced by flow energy. Water levels below $0.5 \mathrm{~m}$ and/or the result of multiplying velocity (v) and height (h) does not exceed $0.5 \mathrm{~m}^{2} / \mathrm{s}$ (where velocity is estimated by the paleohydraulic method).

\section{Conclusions}

Hurricane Mitch is regarded as the reference event in our study area. The geomorphology of the basins favours flashfloods because of the short time elapsed between the rainfall and the flood and because of the short time of high water level permanence. The analysis of the effects of Hurricane Mitch enables us to characterize flooding in this area and to construct flood hazard maps useful for the communities that inhabit the alluvial fans located in the lower reaches of the channels.

The lack of good, detailed data obliged us to use the available data and documents, which we used with a geomorphological perspective. The method includes well known techniques (interpretation of aerial photographs, compilation of historical references, field survey and eyewitness reports). The geomorphological evidence obtained was accurately mapped on the aerial photographs on a scale of 1:8000. The integrated geomorphological map, which is the most important document on which this work was based, could then be constructed using these photographs.

The geomorphological evidence was completed and compared with discharges estimated by different methods. It should be pointed out that certain techniques of discharge calculation, which are very often used between engineers and technicians, can lead to erroneous results when applied to extreme magnitude floods. Flash-floods have an enormous capacity for erosion and sedimentation and reshape the channels. Another limitation of these methods is that a large amount of transported material, which characterises flash floods, is not considered in the hydraulic calculations. In addition, if equations are applied using uncertain data (i.e. short rainfall series) or unreal hypotheses, the results could be even more erroneous. Geomorphological evidence, including the alluvial fan scenario in this case, is useful to evaluate the goodness of the results obtained with other methods.

The historical memory of the communities resides in the oldest members. Although this is a valuable source of information, these persons can only produce information for a period not exceeding 80 years. A hazard map based on flood return periods was not considered because of insufficient historical data. Given the available geomorphological information (the integrated geomorphological map), it is possible to construct a flood hazard map as a function of variables related to flood energy e.g. size of the sediment transported, water height, flow velocity, etc.

It should be noted that the lifetime of flood hazard maps is finite. During floods, water will flow preferentially through the channels that were reshaped by Hurricane Mitch. For extreme events with a magnitude similar to or higher than Mitch, channel reshaping can occur because of the high dynamic activity generated in the alluvial fans. Changes in the geomorphology will lead to changes in future floods. Flood hazard maps constructed with the geomorphological method will continue to be valid until remodelling caused by the next extreme flood. This is applicable to all flood hazard maps.

Thus, the hazard maps obtained using the geomorphological method are reliable because they derive from real data. They are also accurate, simple and relatively cheap. These flood hazard maps achieve a dual purpose: for self-help community emergency plans and for land use planning carried out by the regional authorities.

Acknowledgements. This study has been possible thanks to the agreement between the World Geologists NGO and the Departament de Geodinàmica i Geofísica of the Universitat de Barcelona. The project was financed by the Generalitat de Catalunya and Universitat de Barcelona. The project was supported by the Consolider-Ingenio 2010 programme, under CSD2006-0004“TopoIberia". We are indebted to all the communities that participated in the study such as Puerto Caballo, la Bocana and Salamar. Thanks are also due to all the persons who contributed with their knowledge to our study of the floods caused by Hurricane Mitch in 1998.

Edited by: L. Ferraris

Reviewed by: J.-L. Ballais and another anonymous referee

\section{References}

Agència Catalana de l'Aigua (ACA): Recomanacions tècniques per als estudis d'inundabilitat d'àmbit local, Generalitat de Catalunya, Barcelona, 106pp., 2003.

Alcántara-Ayala, I.: Geomorphology, natural hazards, vulnerability and prevention of natural disasters in developing countries, Geomorphology, 47, 107-124, 2002.

Alcoverro, J., Corominas, J., and Gómez, M.: The Barranco de Arás flood of 7 August 1996 (Biescas, Central Pyrenes, Spain), Engineering Geology, 51, 237-255, 1999. 
Arnaud-Fassetta, G., Cossart, E., and Fort, M.: Hydro-geomorphic hazards and impact of man-made structures during the catastrophic flood of June 2000 in the Upper Guil catchment (Queyras, Southern French Alps), Geomorphology, 66, 41-67, 2004.

Ayala-Carcedo, F. J.: La inundación torrencial catastrófica del camping "LasNieves" del 7 de agosto de 1996 en el cono de deyección del Arás (Biescas, pirineo ADD SPACE aragonés), in: Riesgos Naturales, Una perspectiva global, edited by: AyalaCarcedo, F. J. and Olcina, J., Ariel, Barcelona, 2001.

Baxter, S.: Léxico estratigráfico de El Salvador, CEL, 95pp., 1984.

Ballais, J.-L., Garry, G., and Masson, M.: Contribution de l'Hydrogéomorphologie à l'évaluation du risque d'inondation: le cas du Midi méditerranéen français, Comptes Rendus Geoscience, 337, 1120-1130, 2005.

Benson, M. A. and Dalrymple, T.: General field and office procedures for indirect discharge mesurements, USGS Techniques in Water Resources Investigations, Book 3, Chapter A1, 1967.

Camarasa, A. M. and Segura Beltrán, F.: Flood events in Mediterranean ephemeral streams (ramblas) in Valencia region, Spain, Catena, 45, 229-249, 2001.

Chow, V. T.: Open-channel hydraulics, McGraw-Hill, New York, 680pp., 1959.

Costa, J. E.: Paleohydraulic reconstruction of flash-flood peaks from boulders deposits in the Colorado Front Range. Geol. Soc. Am. Bul., 94, 986-1004. 1983.

Fernandez-Lavado, C.: Caracterización de la inundabilidad por avenidas de tipo flas-flood en el municipio de Jucuaran (El Salvador, CA), unpublished dissertation, Universitat de Barcelona, 151pp., 2006.

Ferrés, D., García, J. C., and Muñoz, C.: Manejo integral de amenazas y vulnerabilidades en el municipio de San Miguel (Departamento de San Miguel), World Geologists (unpublished technical report), 244pp., 2002

Furdada, G., Calderón, L. E., and Marqués, M. A.: Flood hazard map of La Trinidad (NW Nicaragua), Method and results, Nat. Hazards Earth Syst. Sci., in press, 2007.

Guinau, M., Pallàs, R., and Vilaplana, J. M.: A feasible methodology for landslide susceptibility assesment in developing countries: A case-study of NW Nicaragua after Hurricane Mitch. Engineering Geology, 80, 316-327, 2005.

Handmer, J. and Gruntfest, E.: Coping with flash floods. Dordrecht: Published in cooperation with NATO Scientific Affairs Division by Kluwer Academic, cop, 322pp., 2001.
Harrelson, C. C., Rawlins, C. L., and Potyondy, J. P.: Stream Channel Reference Sites: An Illustrated guide to field technique. United States Department of Agriculture, Forest Service, General Technical Report RM-245, 1994.

INETER (Ed.): Las lluvias del siglo en Nicaragua, Managua, 159pp., 1998.

Jarrett, R. D.: Evaluation of the slope-area method for computing peak discharge, USGS Water supply paper 2310, 13-24, 1986.

Jarrett, R. D.: Errors in slope-area computations of peak discharges in mountain streams, J. Hydrol., 96, 53-67, 1987.

Larsen, M. C. and Simon, A.: Rainfall intensity-duration threshold for landslides in a humid-tropical environment, Geografiska Annaler, Series A, Physical Geography, 75(1-2), 13-23, 1993.

Maizels, J. K.: Paleovelocity and palaeodischarge determination for coarse gravel deposits, in: Background to Palaeohydrology: A Perspective, edited by: Gregory, K. J., John Wiley \& Sons Inc., 101-139, 1983.

Ministère de l'Aménagement du Territoire et de l'Environnement (MATE): Risques d'inondation. Plans de prévention des risques naturels (PPR) (La documentation Française), 122pp., 1999.

Montz, B. E. and Gruntfest, E.: Flash-flood mitigation: recommendations for research and applications, Environmental Hazards, 4, $15-22,2002$.

Neumann, A.: Propuesta de definición de clases de peligrosidad para mapas de peligrosidad a fenómenos hidrológicos en Venezuela, Proyecto PREVENE, COSUDE, 10pp., 2000.

Selby, M. J.: Earth's changing surface : an introduction to geomorphology. Repr. Oxford, Clarendon Press, 245-259, 1991.

Témez, J. R.: Jornadas parlamentarias sobre prevención de riesgos relacionados con el agua. Sesión VI. La protección civil ante el riesgo de inundaciones. Madrid, Senado 24 y 25 de noviembre 1997 (policopied example), 1997.

Torrecilla, C., Barrio, J., Mañé, R., Martín, M., Laj, L., FernándezLavado, C.: Análisis Geológico ambiental para el desarrollo comunitario de la asistencia primaria en salud (APS) en el municipio de Jucuarán, World Geologists (unpublished technical report), 244pp., 2003.

Williams, G. P.: Paleohydrologic equations for rivers in Developments and Applications of Geomorphology, 343-367, 1984. 